\title{
Creating a Digital Twin: Simulation of a Business Model Design Tool
}

Kira Rambow-Hoeschele*, Nick Giani Rambow, Matthias Michael Hampel, David Keith Harrison, Bruce MacLeod Wood

School of Computing, Engineering and Built Environment, Glasgow Caledonian University, Glasgow, UK

\begin{tabular}{l} 
A R T I C L E I N F O \\
\hline Article history: \\
Received: 03 December, 2018 \\
Accepted: 02 November, 2019 \\
Online: 22 November, 2019 \\
\hline
\end{tabular}

Keywords:

Business model development

Digital twin

Simulation tool

\begin{abstract}
A B S T R A C T
Digitization forces industry players to adapt to transforming market situations and buyer behavior. Technological advances, buyer power, and sharpened competitive intensity imply that businesses are confronted with the menace of commoditization. For companies to perform successfully in the market, outdated business models ought to be rethought and new business models should be created. Unique selling propositions and differentiation through research, innovation, and holistic stakeholder involvement help industry players to master the change. A tool was built to support businesses facing the consequences of digital transformation: the Business Model Builder. This research paper explores the steps of creating a software version of the analog Business Model Builder. The digital twin enables firms to simulate the iterative adaptation of business models to permanently changing market circumstances and customer demands on an ongoing basis. The user of the tool can edit single variables, understand interrelations, and see the effect on the outcome of the business case, e.g., earnings before interest and taxes or economic value added. Accordingly, the simulation offers the opportunity to have a dynamic view of the business model where any variances of input parameters are reflected in the business case. Thus, profitability, feasibility, and functionality of a business model can be validated, tested, and reviewed in the digital simulation tool.
\end{abstract}

\section{Introduction}

Digitization has an impact on most industries, value-creating architectures, and business models based upon them. The impact depends on the market and can - in several cases will - make current business models outdated.

Digitally connecting devices - TVs, household appliances, watches, etc. -, the Internet of Things creates chances for new business models in $\mathrm{B} 2 \mathrm{C}$ commerce. Nevertheless, they need to be created and implemented as a first step. Furthermore, the Internet of Things substitutes business models in the B2B segment [1].

To adjust current business models to the transforming market situations, or to come up with new business models, the Business Model Builder was developed within the cooperative research project "low-carbon city" [2] - a project, state subsidized by the German Federal Ministry of Education and Research from August 2016 to December 2018 (references 02K12A150 and 02K12A151). The Business Model Builder represents a digital tool

\footnotetext{
${ }^{*}$ Kira Rambow-Hoeschele, Email: kira.rambow-hoeschele@t-online.de
}

that depicts the modules, drivers, and interrelations vital for the development or modification of business models.

\section{Methodology}

The creation of the digital twin simulating a business model design tool follows three major steps: conceptualization and design of the analog Business Model Builder, identification of interdependencies within the tool, and coding of the softwaresupported version to create the digital twin.

\section{Digitization Process of the Tool}

To customize single elements of a business model during its development, and to reveal consequences of changes on the other elements, the Business Model Builder is designed using application software. This software builds a digital twin of the business model. A digital twin stands for to a digital replica of a business model $[3,4]$.

This digital duplicate of the business model simulates adaptations or improvements of e.g., a product involved in the 


\section{K. Rambow-Hoeschele et al. / Advances in Science, Technology and Engineering Systems Journal Vol. 4, No. 6, 53-60 (2019)}

business model. This includes testing the effects on function, handling, visual appearance, etc.

Internal links and databases in the background of the application enable to digitally show how adjustments of individual elements impact other ones. Additionally, the business case is calculated in the tool.

Not merely does the digital version of the Business Model Builder provide an iterative and efficient creation of business models, it also provides real-time information. Through the realtime depiction, transformations of business models can be reviewed in a convenient way.

\section{Reference to Existing Work and Theories}

Over time, the term "business model" has changed and has been defined in various ways. In order to fully comprehend the concept, it is therefore necessary to look at the past definitions as well as future requirements that business models need to fulfill. Business models illustrate a business idea as well as the ways and means by which the idea can be successfully implemented [5]. A business is defined as a product or service that owns a market presence and creates market- and resource-based synergies through collaboration with other entities [6].

Other researchers define the term "business model" as the synthesis of how a company selects its customers, how it defines and differentiates its products, how it structures its internal and external activities, how it uses its resources, how it enters the market, how it creates customer value, and how it earns profits [7]. A business model represents the complete system of how customer value is created and how it is monetized [8]. For several researchers, the elements of value propositions as well as customer segments are of high importance. Moreover, key resources and key activities that are necessary to create customer value as well as revenue streams are considered vital.

According to Timmers, a business model is "an architecture for the product, service and information flows, including a description of the various business actors and their roles and a description of potential benefits for the various business actors and a description of the sources of revenues" [9].

Business models can also be seen as planning and analysis tools. Companies dominating their markets therefore constantly adapt, refine, and develop current or new business models in order to remain competitive [10].

With the new economy boom at the beginning of the current century, the term "business model" was transferred to the business world, as competition was no longer defined as produces and services competing against each other but rather as a clash among various business models [11].

This led to changes in thinking about how to conduct business and where to best allocate resources in order to maximize competitiveness and value creation, since companies no longer possessed competitive advantages due to a superior product or service but rather through the design of complex and advanced business models. Instead of producing a good and simply selling it to the market, the business model needs to tell a reasonable story that is applicable to today's accelerated and more volatile business environment [12].
Moreover, a business model can be defined as a business concept that is applied in the real world. A business concept identifies what value the business is providing to its stakeholders. Also, a business concept is an architecture that should describe how value is generated for customers and business partners. This architecture should include the different steps of value creation. Moreover, it should show how the business model will be able to generate revenues and profits to enable decision makers to identify the value of business ideas and the sustainability of their long-term success [13].

Most researchers see the term "business model" as a simplified depiction of business activities. However, the understanding of the importance of certain aspects of the business model varies [14-17].

Osterwalder and Pigneur define a business model as "nothing else than the value a company offers to one or several segments of customers and the architecture of the firm and its network of partners for creating, marketing, and delivering this value and relationship capital, in order to generate profitable and sustainable revenue streams" [18].

To visualize and to test the realization of business models, they developed the so-called "Business Model Canvas." This is a tool for business model development that can also be used as a checklist to provide an overview of the tasks and requirements that need to be accomplished in order to turn the idea into a real-life business. It is especially helpful to create a common basis for all stakeholders that are involved in the business development process [19].

The concept consists of nine different components that should depict the model in regard to all important parts: customer segments, value proposition, channels, customer relationship, revenue streams, key resources, key activities, key partnerships, and cost structure.

The customer segments component includes consumers as well as businesses. This building block enables a clearer understanding of who the different parties are that are being served by the business. It provides clarity about whom value should be created for and how important those parties are for the business. The different customer segments can be structured according to their needs, their behavior, their specific characteristics, their financial buying power, and their preferred channels.

The value proposition consists of products or services that create value for specific customer segments. This value provided can differ with regard to its nature. It might include performance optimization, branding, work simplification, or entirely new products or services.

The customer relationships component describes how the business interacts with its customers to showcase how it can gain and retain customers. It shows how the relationship between the customer and the company is formed and what kind of relationship they have when conducting business.

The channels component includes all sorts of customer touchpoints as well as the different channels that are used to communicate with the customer and that are needed to distribute and sell the product or service. 


\section{K. Rambow-Hoeschele et al. / Advances in Science, Technology and Engineering Systems Journal Vol. 4, No. 6, 53-60 (2019)}

Key activities include all important activities that are necessary for the entity in order to conduct business. This includes the processes that are needed to create and provide the value proposition to the customer, that are necessary to build and retain customer relationships, and that are used to reach all markets that are relevant for the business idea.

Key resources include all kinds of resources of physical, financial, human, or intellectual natures. This component gives an overview of all resources that are necessary to conduct the business.

In the key partnerships component, the network of all partners and suppliers that are needed for the business idea is described. This might include strategic alliances, joint ventures, and buyerseller relationships.

Moreover, in the cost section of the business model canvas, all kinds of key fixed and variable costs are displayed in order to identify the biggest cost drivers that will affect the profitability of the business.

One of the most pivotal components of this model, however, is the revenue part. This section, in which the actual revenue streams are explained, will ultimately provide guidance on whether the business will be successful or not. This might include revenues from sales, rental services, leasing contracts, advertisements, commissions, or subscription fees.

In the following section, several innovative business model ideas are described. Some have existed for a long time in the business world, while others are comparably new, being enabled through technological developments such as e-commerce.

\section{Innovative Business Model Approaches}

One business model example is the sale of products or services with optional add-on features. This model enables the customer to buy a basic product at a lower price and then be charged a higher amount for additional options. Examples of such business practices can be seen in a variety of businesses such as the airline industry, the automotive industry, or the software industry [20].

A relatively new business model is revenue generation through affiliate links. Through the usage of such links, companies receive a commission based on the generation of sales of products or services through those links. Such business practices are used in ecommerce businesses, e.g., through review or price comparison websites generating additional sales channels for producers [21].

Another prominent business model, especially in the ecommerce sector, is based on auctions. This model enables customers to set the price, leading to higher ambiguity for the seller. Whereas the seller might be able to achieve higher returns in comparison to a traditional sales approach, the business risk increases as the predictability of revenues decreases [22].

Moreover, some companies use a barter approach to acquire new customers by providing free samples of their product. This is often found in the area of consumable products, where potential customers receive a small sample to convince them to convert to paying customers who buy the real product [22].

Bundling and cross-selling approaches capture customers through ecosystems of products and services that, once a customer is acquired, make it rather difficult for them to leave the ecosystem again. Often, technology firms provide a software and hardware ecosystem that enables the customer to synchronize devices and use services on a variety of devices [23, 24].

Another innovative business approach is crowdfunding. This enables companies to make investments they would not have been able to make without the financial support of a broad variety of sponsors [25].

Crowdsourcing business models can be found in a variety of industries. Some companies only try to focus on their specific area of expertise and follow a crowdsourcing approach instead of a vertical integration approach, leading to potential cost savings and more flexibility [26].

Moreover, some companies base their business model on customer loyalty. Many of those companies earn revenues through the collection and analysis of data that is gained from customers who profit from customer loyalty programs, paying with their data [27].

An additional business model that has been developing over the past decades with the rise of digital technology is digitalization. Many businesses have been successful in providing digitized content to customers instead of more resource-intensive and less flexible physical content [28].

Furthermore, the development of the internet created higher market transparency for customers as well as companies and established new ways for producers to earn revenues through direct selling. By leaving out intermediaries, businesses can turn profitable and establish new market opportunities that had not existed before [29].

E-commerce business models are currently transforming the retail business and a variety of industries in ways that have not been seen before. Through lower costs, targeted advertising, broader product offerings, and further advantages, these businesses threaten many well-established companies [30].

Other businesses use flat-rate business models that require users to pay a specific amount in order to use a product or service to an unlimited extent. This has been visible in the online media world, e.g., for music or movie streaming [31].

Additionally, companies use franchising models that enable large scaling effects. After a concept has been developed and a brand established, e.g., in the food industry, local business owners pay for the usage of and supply from the brand [32].

A business model that is frequently visible in the web services industry is the freemium model. This allows customers to use a product in a basic form or for a limited time and offers a premium version that must be paid for [33].

An alternative business model that is often used in the web services industry is hidden revenues. Through the display of advertisements or promotions of complementary products, companies are able to generate revenues [31].

Also, many companies track, analyze, and sell customer data collected through a variety of channels in order to earn revenue. This model is especially used by social media platforms [34]. 


\section{K. Rambow-Hoeschele et al. / Advances in Science, Technology and Engineering Systems Journal Vol. 4, No. 6, 53-60 (2019)}

Intellectual property that might have not been commercialized in the past can be monetized through licensing. Many software firms base their business models on this architecture [33].

Furthermore, through easier accessibility and lower costs due to digitization, long-tail business models have been created that offer products and services that include not only mass products but also niche products that have now become profitable due to economies of scale and lower barriers of entry into a market [35].

Another business model, which became attractive to companies over the past decade, is mass customization, allowing customers to buy products that are mass-produced but customized for them. This has been enabled through technological developments in production, e.g., 3D printing, as well as automation of processes and further technologies. Exemplary industries are the automotive sector as well as the technology hardware sector [36].

Moreover, through lean startup approaches and the reduction of certain product features, no-frills business models have enabled market entry for lower-cost products. A variety of consumable product companies have been established that focus on specific, highly demanded features of a product while leaving out less important features in order to reduce price and increase product attractiveness as well as market attractiveness [37].

Other companies might use open source business models that allow external parties to improve the product. This is a commonly used approach in the software industry, where developers use certain tools that are more adaptable than standard software [38].

An approach that creates flexibility in regard to pricing is the "pay what you want" business model. This architecture can be found in, for example, the cultural sector or the web application sector [39].

With an increased usage of data analytics, pay-per-use business models have become more viable over the past years. Mobility services providers have been using this business model extensively [31].

The razor and razor blade business model architecture is also seen quite frequently in today's consumables industry. Oftentimes, a basic product is provided at a low cost or even free. However, when a replacement of particular parts is needed, the purchase of those parts is more cost-intensive for the customer [33].

A very prominent business model, especially in the web-based industry, is a subscription architecture. This enables companies to earn recurring revenues that might lead to less price-sensitive customers who accept their current costs due to automatic payments. They thereby receive products or services periodically, such as consumables, media, or clothing [40].

Finally, everything-as-a-service (XaaS) business models have been seeing an increasing presence over the last years. In particular, in the software industry, product purchases have been transformed into consuming a service [41].

Those briefly introduced business models are only examples of currently existing business models and should not be seen as an exhaustive list. However, they give a good indication of the variety and complexity of business models that exist nowadays. The aforementioned business models are not only used exclusively but are often implemented as a combination of different models. Due to the potential complexity of business models, it is of high importance to use a development approach that is comprehensive, easy to understand, and flexible to changes.

\section{Comparative Analysis of Business Model Definitions and Elements}

The creation of a business model consists of multiple connected subcomponents, which build several components, which again join up to form modules. The business model building tool presents the individual elements of a business model and their underlying logic. The Business Model Builder is shown in low granularity in Figure 1.

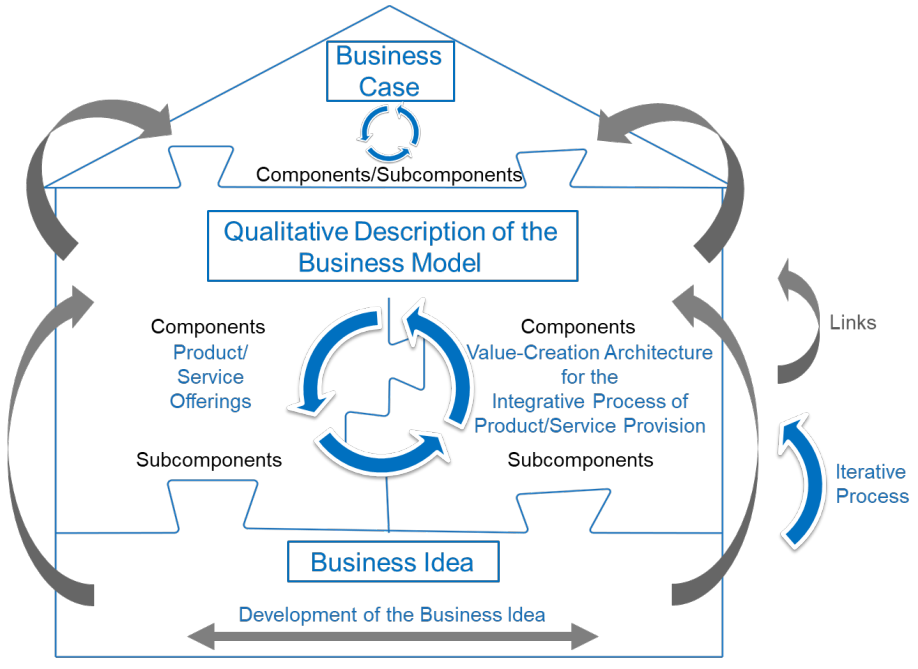

Figure 1: Business Model Builder Depicted in Low Granularity

The application of the Business Model Builder provides the user with business-specific yield numbers indicating the anticipated commercial performance of a business model. The application and field test of the analog Business Model Builder were a success [1].

There have been some former approaches for the creation of business models, e.g., from Gassmann et al. (2013) [42], Schallmo (2013) [43], Osterwalder and Pigneur (2011) [19], or Timmers (1998) [9]. These approaches often consist of diverse checklists, which are mainly grounded on theoretical concepts.

Including all important business model elements, a comparison and evaluation of established business model definitions took place (Figure 2) [7, 9, 10, 13, 15-18, 29, 40, 42-47].

Business models are built of several single elements with differing effect on the outcome of the business case. Various approaches for the creation of a business model can be chosen. For the digitization process of a business model creation tool, nonetheless, it is relevant to individually list all parts. This breakdown eases converting the impact and interrelationships of the single parts into a digital tool since precise relations can be assigned.

To comprehensively include all characteristics required for the development of the digital twin, the Business Model Builder was developed, originating from and enhancing former concepts. 
As mentioned earlier, a checklist lacks some details for the complete development of a business model. Every business model requires a well-considered idea as its basis. Several checklists and related concepts still need to examine the soundness of a business idea and review the concept for its resistance. More than fifty percent of new business formations fail [48]. A key reason are unsustainable business ideas [49].

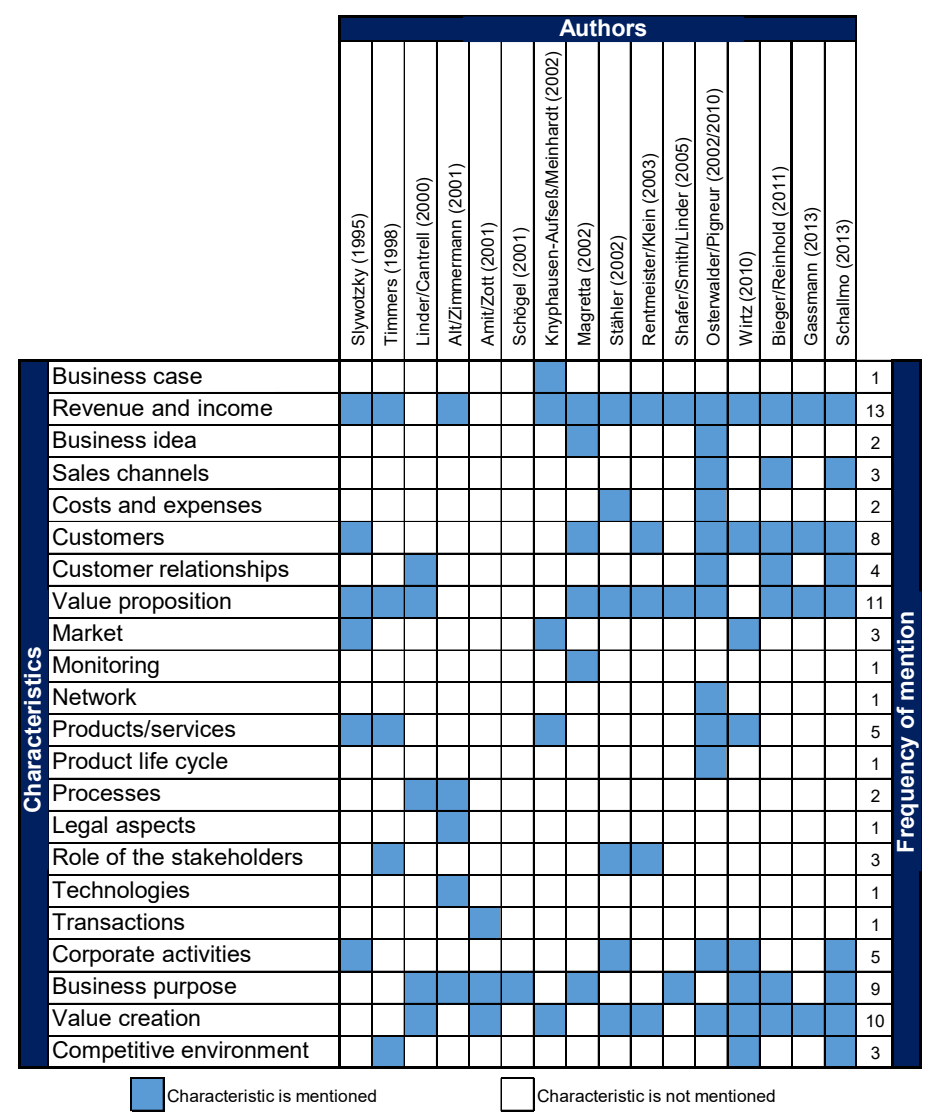

Figure 2: Comparative Analysis of Existing Business Model Theories

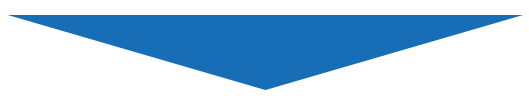

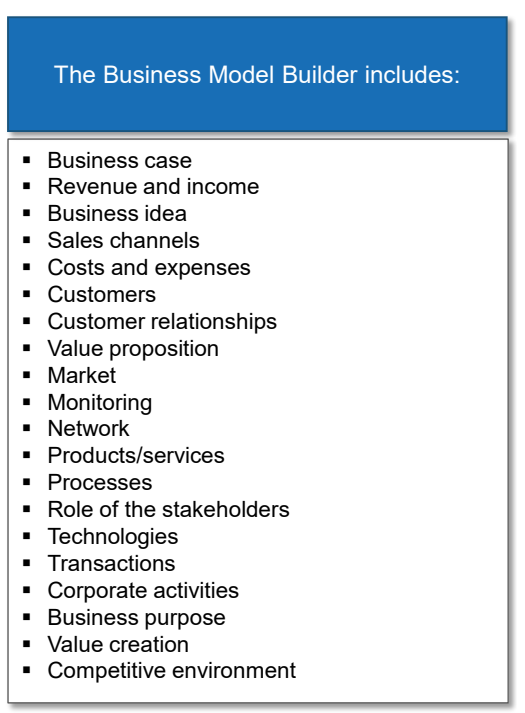

Figure 3: The Business Model Building Tool Extends the Existing State of Knowledge
Figure 3 shows that the Business Model Builder involves all characteristics that are vital for the success of a business model. The tool structures the elements to give a thought-out overview pursuing a distinct logical pattern. The goal of this tool is to enable effective creation of business models.

Compared to the concepts reviewed in Figure 2, the business model building tool follows an explicit architecture to allow for an adjustment of customer demands during and after the process of developing the business model. Pivotal advantages are that the application of this approach is both dynamic and iterative.

Some existing software-supported tools for the creation of business models offer the visualization of the business model elements. However, interrelated effects among the parts are not yet disclosed and precise figures, e.g., of the business case, are not yet calculated.

The software-based version of the business model building tool bridges this gap by paying attention on how individual parts impact each other. Also, business-specific earning numbers are calculated as a result. The digital tool of the Business Model Builder represents a self-contained, cohesive system.

\section{Research and Innovation Approach}

Within the state-subsidized project, various business ideas were created with the aid of the Business Model Builder for the loading of electric vehicles with self-produced electricity, generated by photovoltaic plants.

The single elements of the Business Model Builder are shown in Figure 4. The subcomponents of the tool form components, which sum up to condensed modules. These modules build on one another. Derived from the current state of research, the order of the subcomponents represents a recommendation on how to develop the business model step by step.

\subsection{Module 1: Business Idea}

The first module works as an idea filter for business ideas identified as fruitful. The value proposition is investigated from the customer's point of view and reviewed with regard to an implementation in the market.

\subsection{Module 2: Qualitative Description of the Business Model}

This module comprises of the components product/service offerings as well as creation of offerings / value creating architecture, characterizing the business model under development or revision.

At the end of this process, a definite product/service offering is determined, including a rise in quantity and price on one side and a defined value creating architecture with respective quantities and specific costs on the other side

\subsection{Module 3: Business Case}

The core of this module is the measurement of how performant a business model will be. The success is quantified by key performance indicators, e.g., earnings before interest and taxes or economic value added. The basis, therefore, includes selling volume and price as well as production volume and costs from the second module. The business case - as a quantified business model - can also serve as the foundation for negotiations with investors, for instance. 


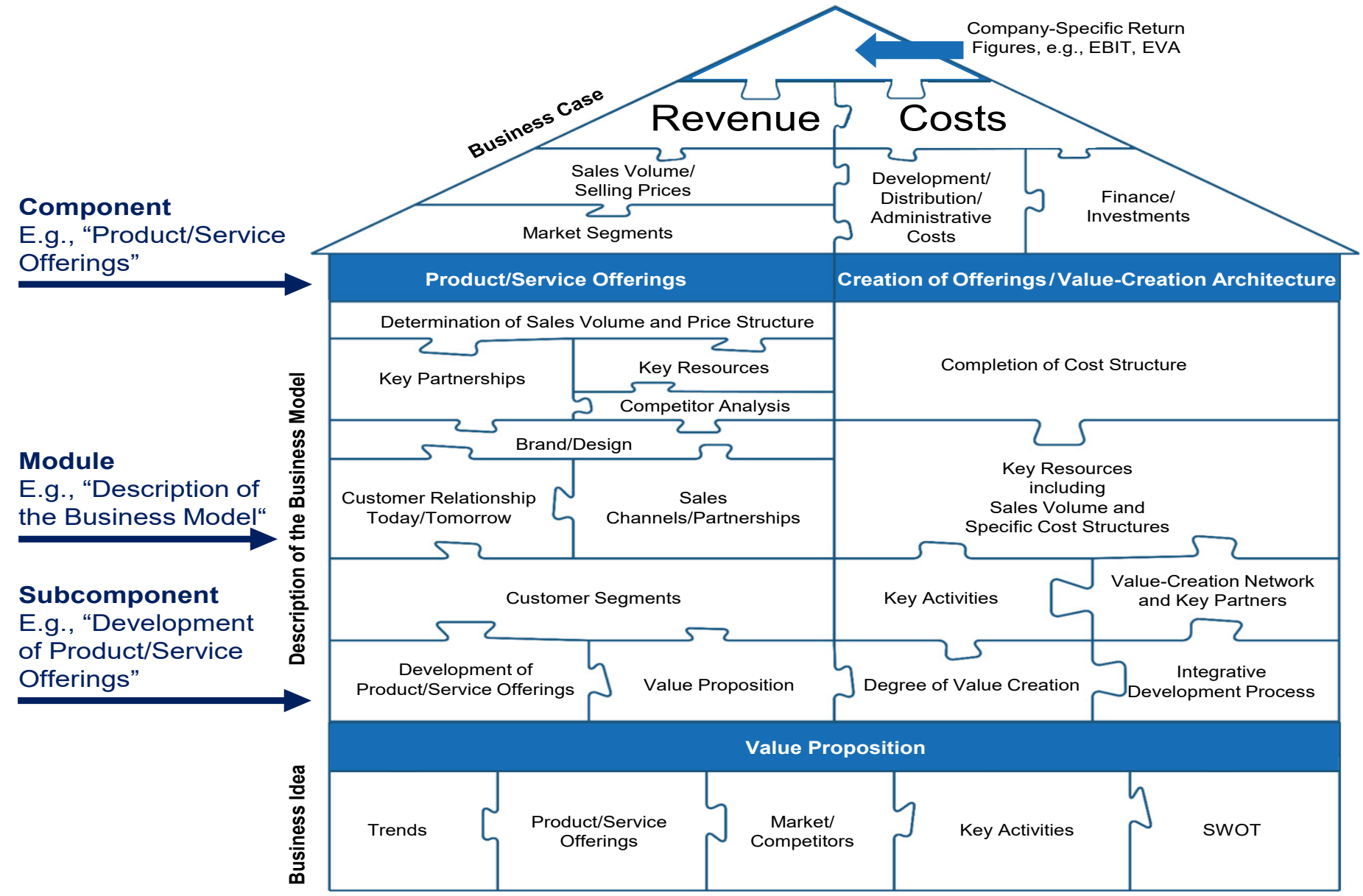

Figure 4: Business Model Builder Depicted in Fine Granularity

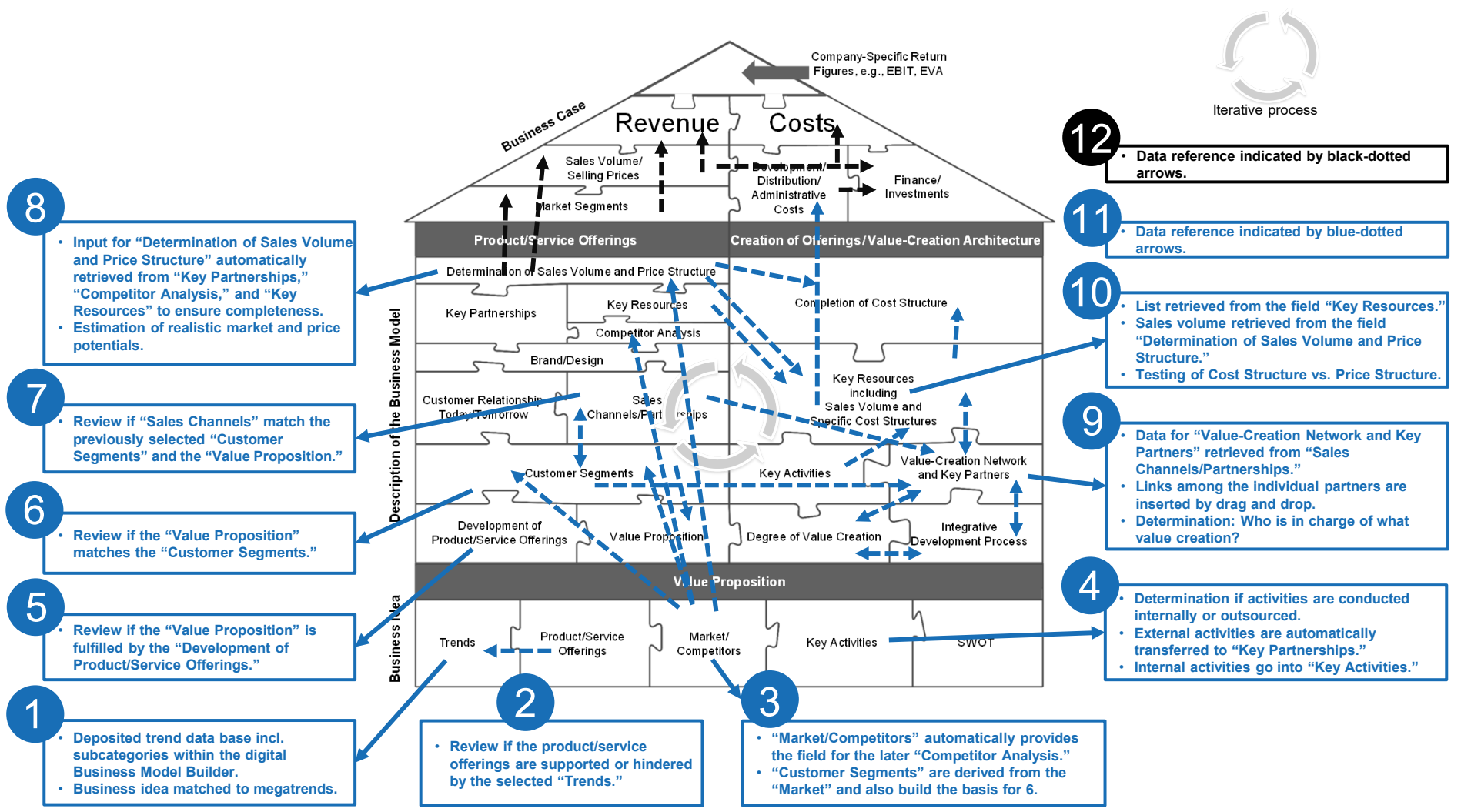

Figure 6: Interdependencies Within the Software-Supported Version of the Business Model Builder 


\section{Conceptualization of the Tool and Its Digital Twin}

The Business Model Builder is designed such that interrelated elements are linked and that effects from changes in one part on another part are revealed. Depending on the input variable, a change can also affect the business case.

The digitization of the Business Model Builder facilitates complex analyses. As multiple elements of the tool depend on other elements and are automatically updated through the links, impact on business results is easily uncovered and visualized.

Figure 5 depicts the schematic setup of the software-based tool. The user is responsible for the input of the elements. The elements automatically match as well as offset against each other. Hence, the operational results are automatically calculated.

Besides, the tool checks the user's input for plausibility and impact on other business model elements. In case of a mismatch, the user is given an error warning, and they are asked to reassess and correct the data entry.

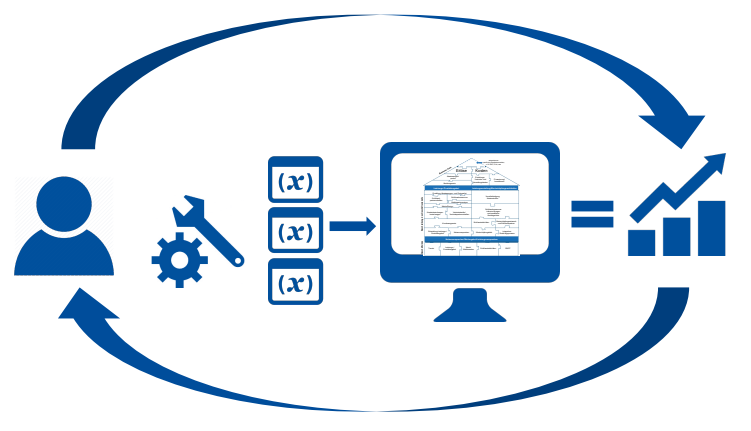

\section{Digitization Process of the Tool and Elaboration of Interrelations Among Elements}

To digitize the business model building tool, it is pivotal to define which elements are freely definable, which import data from deposited databases, and which are the result of interrelated elements. The details of the interdependencies are shown in Figure 6. For the creation of this tool, all elements are studied for their impact on other elements involved. After the definition of these links, the attendant effects are programmed within the application software. This automizes the steps for the iterative business model development.

Providing an example, the first subcomponent in the tool is the trends. The trends are drawn from an external database. Thus, the user assigns their business idea to a megatrend at first. Subsequently, the idea is assigned to the macrotrends related to the megatrend. Later, the trends chosen are collated with the subcomponent "product/service offerings" to check the content of these subcomponents is consistent.

In addition to the yield numbers, the software-based version of the tool generates a digital twin of the business model. This offers convenient further editing of the business model. For instance, if the figures of the business case calculation lead to a "no go" decision, the subcomponents of the business model can be edited so that yield numbers finally result in a "go" decision. The digital Business Model Builder offers users to gradually adapt and improve the digital twin over the total lifetime.

\section{Findings}

Digitizing the Business Model Builder, an instrument is developed enabling users to create new, or innovate current business models in a convenient and structured manner with the desired granularity. In the software-based version of the business model building tool, the elements are automatically interconnected. Hence, business models can be modified, and results can be simulated. The tool can holistically depict the complete lifecycle of business models. Thus, various scenarios can be simulated with little expenditure of human labor and time.

\section{Limitations}

At this phase of the research project, the coding of the digital twin is taking place. As a next step, pilot testing will be implemented to test the application under real-world conditions, collect feedback, and potentially revise and adjust the tool. Only after the rollout will it be possible to see the impact of how the digitized Business Model Builder enhances effectiveness and efficiency of businesses.

\section{Conclusion}

Digitization pushes businesses aiming for sustainable commercial success to adapt business models to new market situations or create new business models when the former ones become obsolete through technological change. The Business Model Builder was developed to serve this demand. As digital version, the tool enables the permanent iterative adaptation of business models to transforming market circumstances.

The software-based version of the tool allows firms to set up their current business models in a digital twin. In this way, firms have the possibility to conveniently simulate amendments to business models and review their profitability, functionality, and feasibility. Furthermore, new business models can be created, validated, and tested. The digital tool offers established businesses as well as start-ups the option to iteratively adapt their business models to continuously transforming market situations and customer demands over a lifecycle. The tool's mission is to support firms in growing sustainably, in generating and keeping unique selling propositions to stand their ground in the market, and in achieving durable success in the world's markets.

\section{References}

[1] A. Nagl and K. Bozem, Geschäftsmodelle 4.0-Business Model Building mit Checklisten und Fallbeispielen. Wiesbaden: Springer Gabler, 2018. ISBN 978-3-658-18841-2

[2] Hochschule Aalen für Technik und Wirtschaft, "BMBF Cooperative Research Project $\mathrm{CO}_{2}$-arme Stadt / Low-Carbon City." Accessed: February 1, 2018. [Online]. Available: www.co2-arme-stadt.de

[3] S. Boschert and R. Rosen, "Digital twin - the simulation aspect," in Mechatronic Futures, P. Hehenberger and D. Bradley, Eds. Cham: Springer, 2016. DOI 10.1007/978-3-319-32156-1_5

[4] M. Grieves and J. Vickers, "Digital twin: Mitigating unpredictable, undesirable emergent behavior in complex systems," in Transdisciplinary Perspectives on Complex Systems, J. Kahlen, S. Flumerfelt, and A. Alves, Eds. Cham: Springer, 2017. DOI 10.1007/978-3-319-38756-7_4

[5] A. Nagl, Der Businessplan: Geschäftspläne erstellen - Mit Checklisten und Fallbeispielen. Wiesbaden: Springer, 2015.

[6] R. Grünig and R. Kühn, Methodik der strategischen Planung: Ein prozessorientierter Ansatz für Strategieplanungsprojekte. Bern: Haupt, 2000. 
[7] A. J. Slywotzky, Value Migration: How to Think Several Moves Ahead of the Competition. Boston: Harvard Business Press, 1995.

[8] A. Zolnowski and T. Böhmann, "Grundlagen service-orientierter Geschäftsmodelle," in Service-orientierte Geschäftsmodelle: Erfolgreich umsetzen T. Böhmann et al., Eds. Berlin: Springer, 2013, pp. 1-29.

[9] P. Timmers, "Business models for electronic markets," Electronic Markets, vol. 8, no. 2, pp. 3-8, 1998.

[10] J. Linder and S. Cantrell, Changing Business Models: Surveying the Landscape. Chicago: Institute for Strategic Change, Accenture, 2000. Accessed: April 12, 2016. [Online]. Available: businessmodels.eu/images/banners/Articles/Linder_Cantrell.pdf

[11] G. Hamel, Leading the Revolution. Boston: Harvard Business School, 2000.

[12] B. W. Wirtz, Business Model Management: Design - Instrumente Erfolgsfaktoren von Geschäftsmodellen. Wiesbaden: Springer Gabler, 2010.

[13] P. Stähler, Geschäftsmodelle in der digitalen Ökonomie: Merkmale, Strategien und Auswirkungen. Lohmar: Eul, 2002.

[14] P. Stähler, Merkmale von Geschäftsmodellen in der digitalen Ökonomie. Köln: Eul, 2001.

[15] D. Knyphausen-Aufseß and Y. Meinhardt, "Revisiting strategy: Ein ansatz zur systematisierung von geschäftsmodellen," in Zukünftige Geschäftsmodelle, T. Bieger et al., Eds. Berlin Heidelberg: Springer, 2002, pp. 63-89.

[16] J. Rentmeister and S. Klein, "Geschäftsmodelle ein modebegriff auf der waagschale," Zeitschrift für Betriebswirtschaft, Ergänzungsheft 1, pp. 17-20, 2003.

[17] S. M. Shafer, H. J. Smith, and J. C. Linder, "The power of business models," Business Horizons, vol. 48, no. 3, pp. 199-207, 2005.

[18] A. Osterwalder and Y. Pigneur, "An e-business model ontology for modeling e-business," Electronic Commerce Conf., Bled, 2002.

[19] A. Osterwalder and Y. Pigneur, Business Model Generation: Ein Handbuch für Visionäre, Spielveränderer und Herausforderer. Frankfurt a. M.: Campus, 2011.

[20] O. Gassmann, K. Frankenberger, and M. Csik, The Business Model Navigator: 55 Models That Will Revolutionise Your Business. Harlow: Pearson. 2014.

[21] M. A. Rappa, "The utility business model and the future of computing services," IBM Systems Journal, vol. 43, no. 1, pp. 32-42, 2004.

[22] M. Dubosson-Torbay, A. Osterwalder, and Y. Pigneur, "E-business model design, classification, and measurements," Thunderbird International Business Review, vol. 44, no. 1, pp. 5-23, 2002.

[23] C. Zott and R. Amit, "Business model design: An activity system perspective," Long Range Planning, vol. 43, no. 2-3, pp. 216-226, 2010.

[24] D. J. Teece, "Strategies for managing knowledge assets: the role of firm structure and industrial context," Long Range Planning, vol. 33, no. 1, pp. 35-54, 2000.

[25] P. Belleflamme, T. Lambert, and A. Schwienbacher, "Crowdfunding: An industrial organization perspective," prepared for the workshop Digital Business Models: Understanding Strategies, Paris, June, 2010, pp. 25-26.

[26] D. C. Brabham, "Crowdsourcing as a model for problem solving: An introduction and cases," Convergence, vol. 14, no. 1, pp. 75-90, 2008.

[27] N. A. Morgan and L. L. Rego, "The value of different customer satisfaction and loyalty metrics in predicting business performance," Marketing Science, vol. 25 , no. 5, pp. 426-439, 2006.

[28] J. Gray and B. Rumpe, "Models for digitalization," Software \& Systems Modeling, vol. 14, no. 4, pp. 1319-1320, 2015. DOI 10.1007/s10270-0150494-9

[29] J. Magretta, "Why business models matter," Harvard Business Review, vol. 80 , no. 5 , pp. 86-92, 2002.

[30] K. C. Laudon and C. G. Traver, E-commerce: Business, Technology, Society. Harlow: Pearson, 2016.

[31] E. Fleisch, M. Weinberger, and F. Wortmann, Business Models and the Internet of Things: Interoperability and Open-Source Solutions for the Internet of Things. Cham: Springer, pp. 6-10, 2015. DOI 10.1007/978-3319-16546-2_2

[32] W. Gillis and G. J. Castrogiovanni, "The franchising business model: An entrepreneurial growth alternative," International Entrepreneurship and Management Journal, vol. 8, no. 1, pp. 75-98, 2012.

[33] D. J. Teece, "Business models, business strategy and innovation," Long Range Planning, vol. 43, no. 2-3, pp. 172-194, 2010.
[34] R. Amit and C. Zott, "Creating value through business model innovation," MIT Sloan Management Review, vol. 53, no. 3, pp. 41-49, 2012.

[35] C. Anderson, The Long Tail: Why the Future of Business is Selling Less of More. New York: Hachette Books, 2006.

[36] F. Salvador, P. M. De Holan, and F. Piller, "Cracking the code of mass customization," MIT Sloan Management Review, vol. 50, no. 3, pp. 71-78, 2009.

[37] M. W. Johnson, C. M. Christensen, and H. Kagermann, "Reinventing your business model," Harvard Business Review, vol. 86, no. 12, pp. 57-68, 2008.

[38] H. W. Chesbrough, "Why companies should have open business models," MIT Sloan Management Review, vol. 48, no. 2, p. 22, 2007.

[39] J. Y. Kim, M. Natter, and M. Spann, "Pay what you want: A new participative pricing mechanism," Journal of Marketing, vol. 73, no. 1, pp. $44-58,2009$.

[40] A. Osterwalder and Y. Pigneur, Business Model Generation: A Handbook for Visionaries, Game Changers, and Challengers. New Jersey: Wiley, 2010

[41] P. Banerjee et al., "Everything as a service: Powering the new information economy," Computer, vol. 44, no. 3, pp. 36-43, 2011. DOI 10.1109/mc.2011.67

[42] O. Gassmann, K. Frankenberger, and M. Csik, Geschäftsmodelle entwickeln: 55 innovative Konzepte mit dem St. Galler Business Model Navigator. München: Hanser, 2013.

[43] D. Schallmo, Geschäftsmodell-Innovation: Grundlagen, bestehende Ansätze, methodisches Vorgehen und B2B-Geschäftsmodelle. Wiesbaden: Gabler, 2013.

[44] R. Alt and H.-D. Zimmermann, "Introduction to special section: Business models," Electronic Markets, vol. 11, no. 1, pp. 3-9, 2001.

[45] R. Amit and C. Zott, "Value creation in e-business," Strategic Management Journal, vol. 22., pp. 493-520, 2001.

[46] K. Schoegel, Geschäftsmodelle: Konstrukt-Bezugsrahmen-Management. München: FGM, 2001.

[47] T. Bieger and S. Reinhold, "Das wertbasierte Geschäftsmodell: Ein aktualisierter Strukturansatz," in Innovative Geschäftsmodelle, T. Bieger et al., Eds. Berlin Heidelberg: Springer, 2011, pp. 11-70.

[48] C. Triebel and C. Schikora, "Scheitern bei Unternehmensgründungen," in Failure Management, S. Kunert, Ed. Berlin Heidelberg: Springer, 2016, pp. 235-248.

[49] J. Egeln, U. Falk, D. Heger, D. Höwer, and G. Metzger, Ursachen für das Scheitern junger Unternehmen in den ersten fünf Jahren ihres Bestehens. Mannheim Neuss: Zentrum für Europäische Wirtschaftsforschung, 2010. 